\section{Jerome Zanchi, the Application of Theology, and the Rise of the English Practical Divinity Tradition*}

PATRICK J. O’BANION

Cet article s'inscrit dans le débat récemment relancé sur la relation entre les théologiens scolastiques de la Réforme et les premiers réformateurs, mais propose également de l'amener dans une nouvelle direction. On y analyse d'abord la doctrine de Dieu, telle que développée par Jerome Zanchi (1516-1590), en mettant en relief comment il passe de conclusions de théologie systématique à des implications de théologie pratique, en particulier, à travers son usage de la convention dite de l'usus doctrinae. L'article cherche ensuite à estimer l'impact de cette convention en dehors des milieux érudits en explorant la relation entre le discours de Zanchi et la tradition anglaise pratique de la divinité. On y met donc en lumière comment les pasteurs et les théologiens populaires ont emprunté à Zanchi dans le cadre de leur charge d'âmes et de réforme de la nation anglaise.

Two early modern likenesses of the Italian exile and Reformed theolo1 gian Jerome Zanchi (1516-1590) exist. ${ }^{1}$ The first, the work of Hendrik Hondius, was published in his Icones virorum nostra patrumque memoria illustrium (1599). The second, probably engraved by Theodore de Bry, was included in Jean-Jacques Boissard's Bibliotheca chalcographica (1669). Beneath each engraving, the artists added a few lines of Latin verse celebrating Zanchi's life. Although there are differences between the verses in the two works, both agree that Zanchi was nulli pietate secundus: second to none in piety. And this description must make modern readers pause and consider. Historiographically, Zanchi's significance is understood to reside in his role as a rigorous codifier and systematizer of Calvinist doctrine at the end of the movement's initial creative phase of existence. In particular, interpreters have suggested that Zanchi's importance resides in a special emphasis that 
he placed on predestination and in the commingling of Aristotelian scholasticism and Reformed theology, not in pietas.

Thirty years ago one scholar summed up the state of the question as follows: "predestination does not have the central controlling role in Calvin's thought that 19th century scholars gave it," but it "did achieve this centrality in the Synod of Dort and most 17th century Calvinism. It was also the central doctrine for [Peter] Martyr [Vermigli] and Zanchi."2 Anyone familiar with the study of Reformed orthodoxy or Protestant scholasticism in the postReformation era will recognize in that quotation a standard trope: that a shift occurred in Reformed theological content and method during the late sixteenth and the seventeenth centuries, away from the Christocentric theology of Luther and Calvin, who were obsessed with issues of salvation, toward an institutionalized Aristotelian scholasticism that replaced Christ with predestination and causality. ${ }^{3}$ In recent years, this thesis has been challenged with regard both to its sweeping generalizations and to the particular examples of theologians that had been marshalled to support it. ${ }^{4}$

This article purposes to move that discussion in a new direction by first carefully examining the doctrine of God as it was propounded by Zanchi and then gauging the impact of his approach to theology on certain religious and cultural developments in the Reformed world. The tome in which Zanchi most significantly discussed matters pertaining to theology proper was his massive and massively influential De natura Dei, seu de divinis attributis, first published in Heidelberg in 1577.5 One of the most important clues for understanding what Zanchi was doing in De natura Dei, a clue that has been almost entirely ignored, is the convention designated the usus doctrinae, the use of the doctrine. By means of that convention Zanchi sought to drive his systematic theological conclusions toward practical theological application. That is to say, when weight is given to the structural and methodological role played by the usus doctrinae in De natura Dei it becomes clear that a major thrust of the book pushes toward the spiritual health of believers. Furthermore, rather than remaining confined to Latin folio volumes, Zanchi's usus convention had a striking impact on the practical divinity tradition in early modern England where it was adopted by pastors and popular theologians to aid them in, not distract them from, the care of souls and the reformation of the English people. Ultimately, Zanchi's approach to theology proper is at least as important for its influence on the development of Protestant practical theology as it is for any special emphasis on predestination or its use of an Aristotelian scholastic method.

In 1961 Otto Gründler submitted a doctoral dissertation to the faculty of Princeton Theological Seminary entitled "Thomism and Calvinism in the 
Theology of Girolamo Zanchi (1516-1590).” This dissertation, which was subsequently translated by Gründler into German and published in 1965, was a study of De natura Dei. And although it is now more than 40 years old, it remains the most frequently cited piece of research on Zanchi, whom Gründler interpreted in the following way: "[I]t would be possible to present Zanchi's teaching on scripture, God, creation, providence, and predestination without ever mentioning Christ, and they would suffer little or no distortion from doing so."6 Furthermore, he explained, "In the theology of Zanchi... one observes a clear shift from the Christocentric orientation of Calvin and Luther toward a metaphysics of causality that henceforth would characterize Reformed orthodoxy."7 In spite of an increasing dissent among Zanchi scholars, ${ }^{8}$ Gründler's analysis of the Italian remains the standard approach in most recent works. ${ }^{9}$

Yet a careful examination of De natura Dei and of Zanchi's usus doctrinae convention demonstrates just how far from the mark the Gründler thesis is. ${ }^{10}$ In fact, the theological systematizing in De natura Dei does not stand on its own as abstruse metaphysical speculation, but finds its significance in the usus convention, which functions as a capstone to each chapter. The usus doctrinae put an emphasis on practical theology and are distinctive for their frequent recourse to Christological language. ${ }^{11}$ For Zanchi, the constructive work of systematic theology and the application of that theology were not in tension, nor were they fundamentally distinct. Indeed, Zanchi's willingness to emphasize doctrinal themes even in the "practical" usus sections of De natura Dei, which are discussed below, should cause modern readers to question whether current assumptions about the distinction between doctrine and the "practical application" of doctrine are adequately sensitive to the early modern parsing of such concepts. This point is born out by the structure of the work itself.

De natura Dei begins with a dedication to Johann Casimir, the second son of Frederick III (r. 1559-1576) and the organizer of the Casimirianum at Neustadt-an-der-Hardt where Zanchi taught while Heidelberg and its university were under Lutheran dominion. The work is then divided into five books spanning more than 700 pages in the 1577 edition. The first book discusses methodological questions and the biblical names of God. Books two through four treat the divine attributes. The three chapters of book five discuss providence, predestination, and the Book of Life. Zanchi employs the usus doctrinae convention 24 times. ${ }^{12}$ Except for the first book, which contains a usus at the end of the first, thirteenth, ${ }^{13}$ and last chapter, every single chapter in De natura Dei has a usus doctrinae. And while some of them are relatively short, others are much longer. The usus for the immut- 
ability, life, and blessedness of God are mere paragraphs, but the usus for the perfection of God spans twelve double-columned folio pages; the will of God, ten; God's providence, nine. Whatever the length of the usus, they are always brief in comparison to the systematic theological analysis that precedes them. As such, the analogy of viewing the usus as capitular capstones seems apt.

In general, a discussion of the usus begins with a comment about the great significance of a doctrine for believers, the remarkable number of ways in which the doctrine can be applied, or perhaps the impossibility of expressing the depth of a doctrine's usefulness. Hence, Zanchi declares, "The use of this doctrine is neither commonplace nor meagre. For what is more excellent than to know that God is most simple?"14 Similarly he wonders, "But who is able to explain the use of this doctrine adequately? Since it teaches, first, which God we love: namely the true God, because He is eternal and the only eternal one." 15 And again, "It cannot be sufficiently explained how various, manifold and great is the utilitas which this doctrine of predestination brings us, as much in regard to reprobation as in regard to election."16 Each usus ends with a declaration of praise to Christ or a laudatory prayer. ${ }^{17}$ But between those bookends, Zanchi offers a remarkably broad and distinct variety of uses for each doctrine. Often, but not always, he divides a usus into multiple sections, delineated by a numeral in the margin, each of which pertains to a specific emphasis.

When multiple emphases are highlighted in the text, the first one Zanchi addresses is often the doctrinal. At times this doctrinal emphasis actually dominates, at least in terms of the amount of time spent on it relative to the other usus. Thus, in the twelve pages devoted to God's perfection, all but a page and a half are focused on doctrinal formulations. ${ }^{18}$ Such doctrinal sections function as summaries of the exegesis done and the conclusions drawn in the preceding chapter at their most fundamental level. Thus, in the discussion of the nature of God in genere, Zanchi draws the conclusions that the doctrine asserts the deity of Christ and the Holy Spirit ${ }^{19}$ and, against Nestorianism and Eutychianism, that it upholds the two natures and one person of Christ. ${ }^{20}$ From the doctrine of God's simplicity, Zanchi draws a declaration of monotheism. ${ }^{21}$ Often, he couches this doctrinal emphasis by pointing out that his preceding systematic work clarifies "what sort of God we love" and thereby distinguishes the Christian God from all creatures and false gods. ${ }^{22}$ Thus, for example, the first use of the doctrine of immutability is "that we might know what sort of God we love, namely the true God because He is immutable. For the true God, who is so by nature, cannot be subject to obnoxious change for any reason."23 
An additional type of usus doctrinae emphasizes the moral implications of the names and attributes of God for the lives of believers. Thus, for Zanchi, if God truly is simple in his character, if he "hates hypocrites, adulterers, double-minded men, and, contrarily, if He loves sincere people and righteous hearts," then Christians too must be simple. God "especially requires of us simplicity of heart because upon that depend all our words and deeds." And from this he concludes, "Those whom God chooses for himself, He makes them simple, like children." 24 Likewise, the hatred of God has implications for Christian morality. For by it, believers are enjoined to "hate the enemies of God, wherever they are, as much as we love God and all of those who love Him." It is not the case, Zanchi clarifies, that Christians should hate the sinners as people, "since they are creatures of God and therefore good," but that Christians should come "to a greater and greater hatred" of the sins themselves. ${ }^{25}$ It is telling that, for Zanchi, the moral implications of a doctrine are not categorically different from the other types of usus. Doctrine, morality, and, as shall be seen below, pastoral care and eschatological identity are all similarly the outworking of theological systematizing.

Closely related to the moral usus is a pastoral emphasis, which offers comfort, encouragement, and warnings to believers. In this vein, Zanchi suggests that one reason why God declares His own immutability is "that we might not have doubts concerning our salvation.” Since God is immutable both according to nature and according to His will and faithfulness and since "He wills and openly reveals this as His will, [i.e., that the elect be saved] and He promised, and also confirmed His promise by swearing" that they who believe in Christ shall have eternal life, "How can we doubt our salvation any longer if we have His promise, He, who is immutable by nature and also by will?”26 A pastor does not only encourage, he also warns of danger. In this spirit, Zanchi warns his readers that God's righteousness is displayed to keep believers from continuing in their sins and "to assure us that, unless we repent, even though God allows us for a time to sin with impunity, nevertheless it will not always be thus, but in the end He will punish us most harshly, but also most righteously."27

Yet, strikingly, it is neither encouragement nor warning that dominates the pastoral usus; rather it is the idea of comfort, particularly comfort as it relates to the assurance of salvation. God's simplicity leads Zanchi to assure those doubting their salvation that if God "is therefore truthful in all His promises, words, acts, and deeds" then there is no need to fret. He grants "eternal life to those who believe in Christ, even if they do not keep the law, even if they commit all the sins that can be committed." God, Zanchi 
assures his readers, "mocks no one and neither desires nor is able to deceive anyone." 28 Therefore His promises are sure.

Likewise, according to Zanchi, predestination is fundamentally a comforting doctrine. Thus, its first use is that by it "we are entirely supported in a sure faith and persuasion, that having overcome all the waves, dangers, and storms of this troubled sea, finally we shall unfailingly be brought through to the port of eternal life by Christ because such is the will and eternal decree of the Father."29 Just as God elects His own unto eternal happiness, He also subjects them "to suffer these temporary afflictions" so that "through all things we might be conformed to the image of His son. Wherefore, just as we rejoice that we are elected unto eternal life, so let us rejoice in tribulations, that by them we might be made like unto Christ." 30 Indeed, in contrast to what the Gründler thesis would lead us to expect, the usus for predestination grounds the doctrine in a strikingly pastoral way, thereby shunning abstruse or speculative concerns. For Zanchi, predestination itself is revealed in scripture not to lead people to wonder whether or not they are numbered among the elect, but in order that "we might be most certain about our salvation because He elected and predestined us that we might be holy and blameless." 31 Whatever trends led troubled souls to search within themselves for assurance of their election, making predestination in certain cases as much a source of psychological torment as of comfort, Zanchi exhibits no awareness of that concern. ${ }^{32}$

Yet another category of usus in De natura Dei is a description of the eschatological implications of specific doctrines for believers, that is, what they reveal about the nature of heavenly life. The basic principle is that "as God is, so shall we be in heaven, where God will be all in all."33 But this principle is worked out carefully and distinctively for individual theological loci. Hence, from God's simplicity, Zanchi concludes that Christians shall be simple, but not as God is simple: "Indeed, no one can be made a simple essence, but neither will there be in us a mixture of sin, lying, hypocrisy, but we will be made most simple in heart, word, and deed, just as God also is simple and trustworthy." 34 From God's eternity Zanchi derives the everlasting heavenly life of believers, but he distinguishes it from God's eternal life since the latter extends infinitely in both directions, the former in only one. ${ }^{35}$ From God's immutability, Zanchi concludes that believers too shall be immutable and no longer susceptible to change but they, unlike God, will be immutable by grace, not by nature. ${ }^{36}$ These insights into eschatological life, however, are not discussed merely as matters of speculative interest. Hard upon Zanchi's declaration of believers' future immutability, for example, he explains the significance of its being revealed: that "we might 
be confirmed in grace in order that we might obtain a firm and immutable happiness with Him."37

The last aspect of the usus doctrinae that this article will address is Zanchi's use of Christological language. It is not usually the case that he devotes a discrete section of the usus doctrinae to this theme in the same way that he does for moral or eschatological matters. Rather, it supports and is integrated into all of the others. Christ is the sun that shines upon creation whereby creatures live, "some for a long time and happily, some less so," through participation in the life of God. ${ }^{38}$ The nearer one draws "to Christ with respect to faith and spirit, the more he is made a partaker of [God's] life." 39 If God is the "cause of all blessedness and is blessedness itself," then blessing must not be sought elsewhere than in Him. But since God was "manifested in the flesh" and "made Immanuel," "all our salvation and blessedness is placed in Christ" and there is nothing more blessed than "to have and hold fast" to Christ. ${ }^{40}$ The foreknowledge of God is "the fount and foundation of our faith," but it is the Holy Spirit who testifies to the truth of this in believers' hearts and it is "unto Christ that [they] have been effectually called." 41 The grace of God leads to redemption "through Christ." 42 Predestination strips away false pride so that "we might receive the whole of our salvation through the grace of God in Christ alone. And so let the one who boasts boast not in himself but in God." 43 Christ is a ship carrying the elect of God "into eternal life" and protecting them "from all danger." 44 Believers have been "conscripted before the foundation of the world, in Christ Jesus our Lord" to fight against the world, the flesh, and the devil until they are at last received into their eternal homeland. ${ }^{45}$

This is far from evidencing Gründler's opinion, quoted at the outset, that as opposed to Calvin, "[I]t would be possible to present Zanchi's teaching on scripture, God, creation, providence, and predestination without ever mentioning Christ, and they would suffer little or no distortion from doing so." 46 There is no indication that Zanchi was inclined to develop a theological approach that would have made such a thing possible. Indeed, this is the significance of the usus doctrinae convention in De natura Dei. It is the sum and end of his constructive theological work. ${ }^{47}$ Zanchi's use of that convention as the capstone of every chapter-not only recapitulating therein the preceding doctrines at their most fundamental levels but also offering moral imperatives, pastoral direction, and heavenly hope all couched in deliberately Christological language-simply cannot be described as an example of "abstruse metaphysical speculations about the being of God." Nor is it true that in Zanchi "a metaphysical interest... became paramount."48 
Before moving on, a couple of suggestions should be offered as to why the approach to Zanchi's theology that emphasizes predestination and metaphysical speculation has had such staying power. First, Zanchi had intended to write a massive multi-volume Reformed systematic theology. Because of the exigencies of life, particularly life in the sixteenth century, he was not able to complete that work. He wrote volumes on the Trinity, the essence and attributes of God, the creation, and part of a fourth volume on the first sin, the fall, and the law. We can only make educated guesses about what Zanchi's pneumatology or eschatology would have looked like when written on a scale equivalent to De natura Dei. In short, we suffer under the disadvantage of having huge treatises on the first half of the theological loci but only biblical commentaries or shorter theological writings on the second half. It is not altogether surprising, then, that scholarly reflection on Zanchi has focused on the work he did on theology proper. But the result of this has been to see Zanchi as a theologian obsessed with knowing the essence of God in a way that the soteriologically-focused early reformers did not. A helpful remedy to this situation would be for those interested in Zanchi's theology to familiarize themselves with the only complete mature presentation of his doctrinal system: his 1585 De religione Christiana fides, which has received almost no scholarly attention to date. While this is not a perfect remedy, it will at least give a broad sense of the way that Zanchi saw the different theological loci interacting with one another.

Second and not entirely unrelated, the point of departure for Gründler's study of Zanchi, which remains the most influential work on the subject and the only modern monograph in any language entirely devoted to Zanchi, ${ }^{49}$ was De natura Dei, a relatively small part of an extraordinarily large body of work. ${ }^{50}$ Because Gründler's study focuses on De natura Dei and because that treatise specifically addresses the subject of theology proper (and not, for example, Christology or soteriology) and because Gründler did not deal adequately even with the practical and Christological elements of De natura $D e i$, the result has been a poor likeness of Zanchi's system broadly considered. This article has sought to address some of those issues, using the usus doctrinae to highlight the way that Zanchi pushed his systematic theology toward practical theology. It would be wrong to discount Gründler's point, that Zanchi draws a great deal of his doctrine of God from Thomas Aquinas and medieval scholasticism, or that Zanchi is Aristotelian and scholastic in a way that Luther and Calvin were not. It would be equally inappropriate to assert that Zanchi's scholasticism amounts simply to metaphysical speculation about the essence of God. 
Yet suggesting that De natura Dei moved in a practical theological direction is not the same as demonstrating that contemporaries saw this as a significant element in Zanchi's work, and furthermore completely fails to consider whether or not anyone came into contact with his methodological approach who was not a highly educated theologian. Indeed, determining the impact of doctrine outside of the realm of doctrinal texts is often a very difficult task. Simply counting the number of times a theologian is mentioned in subsequently published works has the disadvantage of demonstrating contact only in print and does not substantiate any broader impact. Sermons, a medium that bridges the gap between academic theology and parish life, can be of some use. If, either by direct citation or by clear reliance upon a previous theologian's ideas, a debt can be proved, then at least the idea was heard by the lay members of a parish who were in church and awake that Sunday. But, of course, this does not indicate whether the congregation was paying attention or that the sermon had any lasting impact on its auditors. The difficulties of bridging the gap between religious ideas and their broader impact is part of the reason why historians tend to separate the study of the academic theological world from the study of parishes and pastoral ministry. ${ }^{51}$ The former seems generally to be of interest only to historical theologians, while the latter has drawn the attention of a wider audience.

Happily, in this case, it is possible to gesture toward a broader significance for Zanchi's theology. It cannot be shown that his writings directly affected the lives of ordinary early modern men and women; there is no reason to believe that the masses were clambering to acquire their own copies of Zanchi's treatises, even in vernacular translation. But it is at least possible to connect him to the development of an important religious and cultural movement, namely the English practical divinity tradition, and to show the extent to which his praxis-oriented approach to theology was absorbed into the preaching and writing of seventeenth century ministers and theologians.

This turn toward Albion is not as odd as it might initially appear, for it was there that Zanchi found his greatest reception. This is not to suggest that he was unpopular among the Continental Reformed. On the contrary, although Zanchi was still alive when Theodore Beza published his Icones (1580), which fact precluded any possibility of the Italian's inclusion, he was mentioned favourably in Peter Martyr Vermigli's entry as a disciple of the great Italian Reformer. ${ }^{52}$ With Zanchi safely dead in 1599, Hendrik Hondius did include him in his portrait book. ${ }^{53}$ Melchior Adam's Decades duae continentes vitas theologorum exterorum principum (1618) discussed Zanchi and provided the outlines of his life, and his portrait can be found in Jean-Jacques Boissard's Bibliotheca chalcographica (1669). ${ }^{54}$ By contrast, 
it was only in the middle decades of the seventeenth century that Zanchi was numbered among the great modern Protestant divines in English portrait books and popular histories. By then, however, his reputation was well established among English pastors and theologians. ${ }^{55}$ Indeed, it was during the last decade of the sixteenth century and the first two decades of the seventeenth, that the publication and proliferation of Zanchi's writings reached their zenith in England. ${ }^{56}$

Among the works of Zanchi published in England was Life everlasting: or the true knowledge of one Jehovah, three Elohim, and Jesus Immanuel, an abridgement of De natura Dei translated and edited by Robert Hill (d. 1623) and published in Cambridge by John Legate, the university's printer, in 1601. Zanchi is, rather oddly and inexplicably, not listed as the author on the title page, but the source is clear. ${ }^{57}$ Hill had been a student and fellow first at the Puritan stronghold Christ's College, Cambridge and then, from 1589, at St. John's College before moving on to pastoral ministry. He translated and edited the works of moderate puritans like Richard Greenham and William Perkins and was particularly devoted to the latter. Julia Merritt's recent examination of Hill's life suggests that,

At first sight, then, Hill looks like a typical puritan divine. We would presumably expect him to follow a suitably godly career, thundering the doctrine of predestination from the pulpit and dividing his parishioners into sheep and goats. He would be largely cut off from the broad mass of his parishioners, preoccupied with the debates of predestinarian theology and the needs of a small, godly elite.

However, "further examination reveals that Hill was anything but a detached academic." 58 Indeed, according to Merritt, no real disjuncture can be detected between Hill's days in Cambridge as a puritan divine and the more practical concerns he exhibited during his later years as a mature pastor. ${ }^{59}$

The point is well made and fundamentally convincing. However, when Merritt comes to her discussion of Life everlasting, the work does not fit her thesis. She comments that in it Hill "presented an unflinchingly severe doctrine of predestination mostly based on the writings of Zanchius of Heidelberg, which one modern commentator has described as a densely scholastic work filled with 'abstruse metaphysical speculations." "60 But is it appropriate to regard Life everlasting as a singular counterexample to be set to one side because the abundance of evidence points toward the integration of university and parish worlds in Hill's career? I suggest not.

Like De natura Dei, Life everlasting allows for no easy disjuncture between academic and pastoral pursuits. Hill's work contains, perhaps, 80 percent of De natura Dei in fairly loose translation. He regularly summar- 
izes or abridges, and at times he adds his own comments or examples. Yet, like Zanchi, he includes extensive treatments of the usus doctrinae. Far from suggesting that Hill the puritan divine failed in this case to be reconciled with Hill the practically minded pastor, with the usus doctrinae taken into account, Life everlasting becomes a remarkable example of just that sort of integration. In it, the contours of scholastic Reformed theology are funnelled toward pastoral concerns.

Hill's most successful work was Christs prayer expounded, a Christian directed, and a Communicant prepared (1607), published repeatedly from 1609 as Pathway to prayer and pietie. It was a popular catechetical work that Hill initially prepared for his parishioners at St. Martin in the Fields. Yet, in the editions published after 1613, he chose to attach to it a brief theological declaration about the Lord's Supper. Since he was writing to a broad lay audience, not even particularly to an audience of godly elite Puritan laypeople, ${ }^{61}$ it is remarkable that he chose to translate and attach "Mr Zanchivs Confession, concerning that sacrament" to his popular tract. Clearly, Hill saw no great disconnect between the airy theology that Zanchi had produced in the academy and the pastoral work that had to be carried out in the trenches among local congregations. Indeed, for Hill, Zanchi's work must have been viewed as a resource that was particularly useful for carrying out such work.

Nor is Hill the only English pastor/theologian to draw from Zanchi during this time in an attempt to impact popular religious beliefs. William Perkins (1558-1602), whose A golden chaine (1591) Hill translated into the vernacular and whose Lectures upon the first three chapters of the Revelation (1604) Hill edited for publication, also looked to Zanchi in his writings. Perkins was a great popularizer of academic theology who often drew from Continental Reformed scholastic theologians, especially Beza and Zanchi. ${ }^{62}$ In Perkins's devotional work, A case of conscience the greatest that euer was; how a man may knowe whether he be the child of God or no (1592), he included a translation of Zanchi on perseverance, noting in the introductory letter that "to the helping of the simple and unlearned, who desire to be informed concerning their estate, I have propounded these two parts [i.e., his examinations of Psalm 15 and 1 John], in the form of a Dialogue: and have joyned thereunto a little discourse concerning the same matter, penned in Latin by H. Zanchius a learned Divine, and now Englished."63

It cannot simply be the case, then, that Perkins "distinguished himself from his allies on the continent... not so much in the content of his theology, but rather in the pronounced emphasis that he places on the practical application of Reformed theology to the inner spiritual life of the believer and to the Christian's moral life." 64 As has been demonstrated from the preceding 
examination of De natura Dei, Zanchi was already doing this, and Perkins clearly recognized that thrust in Zanchi's published theology or his inclusion of Zanchi in A case of conscience becomes inexplicable.

Indeed, Cambridge University was a hotbed for Zanchian theology, both systematic and practical, in the late sixteenth and early seventeenth centuries. In 1592, the university's printer, John Legate, published an English translation of Zanchi's De spirituali inter Christum et ecclesiam connubio (Herborn, 1591), an extract from his commentary on the book of Ephesians. ${ }^{65}$ Legate would later also be responsible for publishing Hill's translation of De natura Dei as well as a 1599 translation of the last treatise published in Zanchi's lifetime, De religione Christiana fides (Neustadt,1585). ${ }^{66}$ The translators of De religione and De connubio are unknown, but certainly could have been Hill or Perkins or, indeed, any number of other figures.

Richard Greenham (early 1540s-1594), about whom it was said that "his master-piece was in comforting wounded consciences," was the greatest early example of the English practical divinity tradition. ${ }^{67}$ He read theology at Pembroke Hall, Cambridge before becoming minister at Dry Drayton only three miles away, and appears to have been indebted to Zanchi for elements of his sabbatarianism. ${ }^{68}$ For certain, when he arrived at Pembroke Hall in 1559, Edmund Grindal, later Archbishop of Canterbury and a great friend of Zanchi's, was Master. ${ }^{69}$ But even more convincing in this connection, Greenham appropriated the usus convention in many of his printed sermons, all of which appeared in print well after the publication of De natura Dei. ${ }^{70}$ Greenham does not refer to Zanchi, but that is hardly surprising. It would not do for a preacher to cite a scholastic theological treatise just as he turned to show his parishioners how a passage of scripture impacted their lives. In subsequent years, Greenham's parish became a "household seminary" that helped alleviate the lack of experience among young men who had already been academically trained for the ministry. ${ }^{71}$ One can easily imagine Greenham passing along the usus convention to his charges along with the rest of his pastoral wisdom. In 1612, when the collected works of Greenham were published, the editor's dedication to the Fourth Part was written by none other than Robert Hill. ${ }^{72}$

Henry Nelson (fl. 1614), who translated and published three of Zanchi's short treatises on the end of the world, the perseverance of the Saints, and an abridgement of his Praelections under the title Speculum Christianum: a Christian survey of conscience (1614), also had deep Cambridge roots. He wrote in the dedicatory letter to Doctor Stanton and John Newstubs that "you are ancient and kinde friends in faith and loue, and in the fellowship of that famous Society of S. Iohns Colledge in Cambridge."73 When Nelson 
addressed why he chose to translate and publish the treatises of "that graue and learned Divine, Maister Hierome Zanchius” he explained that,

"in Argument and matter they are exceeding effectuall, befitting this sinfull and sottish Age, or rather this degenerating downefall of all sorts of men. They are fruitfull in many considerations; to preuent curiositie; to abandon securitie; to rowze vp the drowsie Christian; to detect the Temporizer; to kindle zeale; to worke vigilancie; to enforce repentance; to minister consolation; to teach the wise; to hearten the weake; to confirme faith and hope of heauen and Happinesse; to dant vngodlinesse...."74

As for Hill, Perkins, and Greenham, so too for Nelson: the particular attraction that Zanchi held did not spring from a desire for speculation about abstract metaphysics, but from their belief that his work was useful for very practical, pastoral considerations.

Cambridge was not the only university in the land where Zanchi was influential. Although the importance of his practical-theological emphasis does not appear to have been so much in the focus at Oxford as in the preceding case, it is still worth pointing out the increasing significance played by Zanchi as a theological force in England generally. In his study of the impact of Reformed theology at Oxford, C. M. Dent expertly identifies "the growing dominance of Beza, Zanchius, and their English popularizer, William Perkins," from the 1580s. ${ }^{75}$ Zanchi especially held sway among Oxford theologians and preachers, who cited him more often than Beza, and Zanchi's works were among the most-frequently donated volumes to college libraries during the period. In 1610, when Sebastian Benefield published his Doctor of Divinity lectures, he cited Luther, Bucer, Calvin, Bullinger, Beza, Junius, Lubbert, Polanus, and Whitaker, but to Zanchi he accorded the honour of being "clarissimus superioris seculi theologus."76

Nor did Zanchi's influence diminish after the 1610s. Indeed, the seventeenth century saw a massive expansion of the usus doctrinae, but, like Greenham, the authors who employed it rarely noted the source of their debt. The greater part of the treatises printed in England during the seventeenth century on theology proper contain elaborate sections devoted to the "uses," occasionally designating them "consectaries," or "applications to edifie." Some of these are works of systematic theology, but others had more parochial origins. John Preston, for one, published a collection of his sermons on theology proper under a title remarkably similar to Hill's abridgement of Zanchi: Life eternal, or, a treatise of the knowledge of the Divine Essence and Attributes (1631). Whether or not these writers cited Zanchi, the convention flourished. ${ }^{77}$ And this flourishing was hardly confined to treatises on the doctrine of God. At least as early as the 1620s, many preachers and 
divines were making use of the usus as a discreet part of their sermons and writings. ${ }^{78}$ In effect, the absorption and spread of Zanchi's usus convention in English preaching and theological writing flowered into the development of a Reformed tradition of practical application for doctrinal themes in a Puritan context.

There is, to be sure, a difference in emphasis between Zanchi's approach and that of his late sixteenth and early seventeenth century English devotees. Hill, Perkins, and Greenham in particular took the practical aspects of Zanchi's theology to an altogether different level. Zanchi's focus may have been on practical theology, but the context was still academic. De natura Dei certainly was not a book for the average layperson. Its audience was theologians, divinity students, and pastors. Even Hill's translation of it cannot be described as popular. But Hill's Pathway to prayer and pietie certainly was, and so too was Perkins's A case of conscience. And these tracts dovetail seamlessly with the growing desire for pastoral works that could be read by and that would impact the lives of what the moderate puritan George Gifford called "the common sort."79 In this light, Zanchi becomes a stepping stone toward, if not the full flowering of, the English Puritan tradition of godly physic and practical divinity.

It is not possible to show that De natura Dei or any of Zanchi's works were the sole or even primary source for the development of that tradition. Religious and cultural developments like the tendency for late Elizabethan and early Jacobean pastors and theologians to devote attention to effecting a reformation from below do not stem from a single source, but arise rather from a complicated matrix of needs and concerns. Yet as Zanchi's Latin writings were read, translated, and published in England they became an important and constructive part of an entire milieu of practical theology. If attention is paid to the types of people who were drawn to Zanchi's writings, including but not limited to De natura Dei, and the ends toward which they were used, there is little reason to believe that he was primarily seen as an abstruse metaphysical speculator. Rather, the weight of evidence suggests that he was viewed as part of a coterie that included the likes of Hill, Perkins, Nelson, and Greenham, men not interested merely in producing academic theology nor in being time-serving ministers, but rather in effecting a greater reformation of religion among the people of England. If Zanchi's inclusion in that group is sure, then we must lay at his feet a share of the responsibility for the development of the English practical divinity tradition. ${ }^{80}$ In any case, if Heinrich Heppe, the great nineteenth century historian of doctrine, could describe William Perkins as the father of pietism, then Zanchi, 39 years 
Patrick J. O’Banion / The Application of Theology /111

Perkins's senior and a major influence on his thinking, must be regarded as its grandfather. ${ }^{81}$ The Italian was, after all, nulli pietate secundus.

\section{Saint Louis University}

\section{Notes}

* The author would like to acknowledge the generous financial and institutional support provided by the H. Henry Meeter Center for Calvin Studies, Grand Rapids, MI, where much of the following research was carried out. The careful readings and thoughtful comments made by the anonymous referees of this journal also deserve thanks. Portions of this article were presented at the Meeter Center and at the Forty-First International Congress on Medieval Studies, Kalamazoo, MI.

1. The standard biographical account of Zanchi's life remains Charles Schmidt, "Girolamo Zanchi,” Studium und Kritiken, 32 (1859), pp. 625-708. But see also Luigi Santini, La comunità evangelica di Bergamo: Vicende storiche, (Torre Pellice: Claudiana, 1960), pp. 228-51; Joseph H. Tylenda, “Girolamo Zanchi and John Calvin: A Study in Discipleship as Seen Through Their Correspondence,” Calvin Theological Journal, 10 (1975), pp. 101-41; and on Zanchi's later life, controversies, and works see Christopher J. Burchill, "Girolamo Zanchi: Portrait of a Reformed Theologian and His Work," in Sixteenth Century Journal, 15 (1984), pp. 185-207.

2. John Patrick Donnelly, "Italian Influences on the Development of Calvinist Scholasticism,” Sixteenth Century Journal, 7 (1976), p. 97. But see Donnelly’s “Calvinist Thomism,” Viator, 7 (1976), pp. 452-53, which suggests a more nuanced interpretation of Zanchi.

3. The clearest presentation of this approach with regard to its implications for understanding post-Reformation Reformed scholasticism broadly is in Basil Hall, "Calvin Against the Calvinists,” in John Calvin, ed. G. E. Duffield (Grand Rapids: Eerdmans, 1966), pp. 12-37 and Brian G. Armstrong, Calvinism and the Amyraut Heresy: Protestant Scholasticism and Humanism in Seventeenth Century France (Madison: University of Wisconsin Press, 1969).

4. See, for example, John Platt, Reformed Thought and Scholasticism: The Arguments for the Existence of God in Dutch Theology, 1575-1650 (Leiden: Brill, 1982); Scott M. Manetsch, Theodore Beza and the Quest for Peace in France (Leiden: Brill, 1997); Carl Trueman, The Claims of Truth: John Owen's Trinitarian Theology (Carlisle: Paternoster, 1998); Willem J. van Asselt, The Federal Theology of Johannes Cocceius (1603-1669), trans., Raymond A. Blacketer (Leiden: Brill, 2001); Willem J. van Asselt and Eef Decker, eds., Reformation and Scholasticism: An Ecumenical Enterprise (Grand Rapids: Baker, 2001); Richard A. Muller, Post-Reformation Reformed Dogmatics, 4 vols. (Grand Rapids: Baker, 2003); and Richard A. Muller, After Calvin: Studies in the Development of a Theological Tradition (Oxford: Oxford University Press, 2003).

5. De natura Dei, seu de divinis attributis (henceforth, DND) (Heidelberg, 1577). A second edition was published in 1590 and a quarto edition in 1598. It was published as part of Operum theologicorum D. Hieronymi Zanchii tomi octo, 8 vols. in 3 (Geneva: Gamonet \& Aubert, 1605), and, consummately, it was included in Zanchi's Opera theologica, 8 vols. in 3 (henceforth, Op. th.) (Geneva: Crespin, 1617-1619), vol. 2, pp. 1-588. I have made a brief comparison of the 1577 edition with the 1617 Crespin edition, which was 
112/ Renaissance and Reformation / Renaissance et Réforme

published by his heirs. Beyond adding a number of paragraph breaks, no obvious changes or emendations occurred.

6. Otto Gründler, "Thomism and Calvinism in the Theology of Girolamo Zanchi (15161590),” (Th.D. Dissertation, Princeton Theological Seminary, 1961), p. 159. The same quotation is used in Gründler's entry for "Zanchi, Girolamo" in The Oxford Encyclopedia of the Reformation, ed. Hans J. Hillerbrand (Oxford: Oxford University Press, 1996), p. 305. See also Gründler, Die Gotteslehre Girolamo Zanchis und ihre Bedeutung für seine Lehre von der Prädestination (Neukirchen-Vlyn, 1965) and "The Influence of Thomas Aquinas upon the Theology of Girolamo Zanchi,” in Studies in Medieval Culture, ed. J. R. Sommerfeldt (Kalamazoo: Western Michigan University Press, 1964), pp. 102-17. Cf. Norman Shepherd, “Zanchius on Saving Faith,” in Westminster Theological Journal, 36 (1973), pp. 31-47, a significant critique of Gründler’s selective use of evidence to prove his thesis.

7. Gründler, “Zanchi, Girolamo,” pp. 305-06. Along similar lines of interpretation, see J. P. Donnelly, "Italian Influences on the Development of Calvinist Scholasticism," pp. 81-101.

8. Two of these dissenters are particularly worthy of note: (1) John Farthing, who has presented Zanchi as a Reformed Thomist whose theology was "clearly in service to a spirituality that stands among the sources of what would become, in the following century, a full-fledged, self-conscious Reformed pietism....” Farthing, "Patristics, Exegesis, and the Eucharist in the Theology of Girolamo Zanchi,” in Protestant Scholasticism: Essays in Reassessment, ed. Carl R. Trueman and R. Scott Clark (Grand Rapids and Carlisle, Cumbria: Baker and Paternoster, 1999), p. 95. (2) Harm Goris, who has emphasized the important role played by analogical speech about God in De natura Dei. Goris, "Thomism in Zanchi's Doctrine of God,” in Reformation and Scholasticism, pp. 121-39.

See also Farthing, “'De coniugio spirituali’: Jerome Zanchi on Ephesians 5:22-33,” Sixteenth Century Journal, 24 (1993), pp. 621-52; “Foedus Evangelicum: Jerome Zanchi on the Covenant," Calvin Theological Journal, 29 (1994), pp. 149-67; "Christ and the Eschaton: The Reformed Eschatology of Jerome Zanchi,” in Later Calvinism: International Perspectives, ed. W. Fred Graham, Sixteenth Century Essays and Studies, XXII (Kirksville: Sixteenth Century Journal, 1994), pp. 333-54; and "Holy Harlotry: Jerome Zanchi and the Exegetical History of Gomer (Hosea 1-3)," in Biblical Interpretation in the Era of the Reformation: Essays Presented to David C. Steinmetz in Honor of His Sixtieth Birthday, ed. Richard A. Muller and John L. Thompson (Grand Rapids: Eerdmans, 1996), pp. 292-312. Along similar lines, see Richard A. Muller, Christ and the Decree: Christology and Predestination in Reformed Theology from Calvin to Perkins (Durham: Labyrinth, 1986), pp. 110-25.

9. Among those works that have appeared over the last two decades that continue to follow Gründler are John von Rohr, The Covenant of Grace in Puritan Thought, AAR Studies in Religion no. 45 (Atlanta: Scholars Press, 1986), pp. 2-4; Alister McGrath, The Intellectual Origins of the European Reformation (Oxford: Basil Blackwell, Ltd., 1987), pp. 192-93; David A. Weir, The Origins of the Federal Theology in Sixteenth-Century Reformation Thought (Oxford: Clarendon Press; New York: Oxford University Press, 1990), pp. 120-21, 156; Alister McGrath., A Life of John Calvin: A Study in the Shaping of Western Culture (Oxford: Basil Blackwell, Ltd., 1990), pp. 211-13; John H. Primus, Richard Greenham: Portrait of an Elizabethan Pastor (Macon: Mercer University Press, 
Patrick J. O’Banion / The Application of Theology /113

1998), p. 89; Philip Benedict, The Faith and Fortunes of France's Huguenots, 1600-85 (Aldershot: Ashgate, 2001), pp. 210-11 (but see his Christ's Church Purely Reformed: A Social History of Calvinism [New Haven: Yale University Press, 2004], pp. 300-05); and J. F. Merritt, “The pastoral tightrope: a puritan pedagogue in Jacobean London,” in Politics, Religion and Popularity in Early Stuart Britain: Essays in Honour of Conrad Russell, ed. Thomas Cogswell, et al. (Cambridge: Cambridge University Press, 2002), p. 146.

10. Harm Goris is the only writer who has noted, even in passing, the usus convention in De natura Dei. See “Thomism in Zanchi’s Doctrine of God,” p. 126. Zanchi does not employ the usus in De tribus Elohim (Frankfurt, 1572), which is not surprising, given that it was written, at the request of Frederick III, largely as a polemic against anti-Trinitarianism. In De operibus Dei (Neustadt, 1591) the convention does occasionally appear but with nothing like its frequency in De natura Dei. See De operibus Dei (in Op. th., vol. 3), pp. 82, 129, 211, 518. At times, Zanchi also does something like the usus without specifically naming it as such: pp. 143, 165, 174, 258.

11. Thinking in terms of doctrinal application for systematic or exegetical theology must have been something of a commonplace during the period of Reformed ascendancy in Heidelberg under Frederick III (r. 1559-1576). The usus convention was employed by Caspar Olevian in his Expositio symboli apostolici (Frankfurt, 1576), and may have been a result of the influence of Peter Ramus. (See R. Scott Clark, Caspar Olevian and the Substance of the Covenant: The Double Benefit of Christ, Rutherford Studies in Historical Theology (Edinburgh: Rutherford House, 2005), pp. 60, 188). Zanchi's and Olevian's colleague Franciscus Junius also made use of usus in his Apocalypsis S. Joannis apostoli et evangelistae, methodica analysi argumentorum, notisque brevibus ad rerum intelligentiam \& catholicae ac christianae ecclesiae historiam pertinentibus illustrata (Heidelberg, 1591). The convention also appears in Guillaume Bucanus, Institutiones theologicae (Bern, 1605).

Assuming that the indebtedness to Ramus is correct, it is perhaps necessary to reconsider the matter of Zanchi's avid Aristotelianism and account for his willingness to use Ramist methodological approaches. See Walter J. Ong, Ramus, Method, and The Decay of Dialogue: From The Art of Discourse to The Art of Reason, with a forward by Adrian Johns (Chicago, 2004), pp. 283-84, 321-22.

12. The usus doctrinae are dispersed thus, with the inclusive page numbers of each in parentheses: on the need for thinking about God's attributes (p. 2); the use of the name Jehovah (pp. 47-51); the names of God (p. 59); the nature of God in general (pp. 75-76); the simplicity of God (pp. 86-87); the eternity of God (pp. 93-100); the immutability of God (p. 100); the life of God (p. 108); the immensity and infinity of God (pp. 167-86 [i.e., 168]); the perfection of God (pp. 176-88); the blessedness of God (pp. 194-95); the omnipotence of God (pp. 234-39); the knowledge of God (pp. 276-77); the truth of God (pp. 293-96); the will of God (pp. 389-99); the goodness of God (pp. 418-20); the grace of God (pp. 438-39); the love of God (pp. 451-53); the mercy of God (pp. 481-82); the righteousness of God (pp. 496-97); the wrath of God (pp. 509-10); the hatred of God (p. 514); the lordship of God (pp. 520-21); the providence of God (pp. 574-83); predestination (pp. 698-710); the Book of Life (pp. 718-19).

13. The thirteenth chapter deals with the Tetragrammaton. 
14. $D N D$, p. 86: "Est porro huiusce doctrinae usus, neque vulgaris, neque exiguus. Quid enim praestantius, quam cognoscere, Deum esse simplicissimum?” All translations of De natura Dei are my own.

15. DND, p. 93: "Quis autem usum huius doctrinae explicare satis queat? Docet cum primis, qualem Deum colamus: verum scilicet Deum: quia aeternus est, \& solus vere aeternus.

16. $D N D$, p. 698: “Quam varia, \& multiplex, magnaque sit utilitas, quam nobis adfert doctrina haec de praedestinatione, hoc est, tam de reprobatione, quam de electione: explicari satis non potest."

17. E.g., $D N D$, p. 59: "Faxit Deus, ut semper divina ipsius nomina, cum vera ipsorum cognitione, nobis ante oculos obversentur: \& quo maior fiet cognitio, eo etiam nos magis \& magis in pietate proficiamus" ("May God grant that his divine names, along with a true knowledge of them, may always be seen before our eyes, and that, the more knowledge we have, we may likewise advance more and more in piety.”); $D N D$, p. 195: "Proinde Scriptura ubique clamat, qui habet Christum, eum habere vitam: \& qui credit in eum, illum itidem habere vitam aeternam: docens, Christum fide recipi, haberi, retineri: eoque per fidem in Christum, nos, \& quaecunque ad Beatitudinem faciunt, recipere: iustificationem, remissionem peccatorum, pacem conscientiae, sanctificationem: \& tandem in plenam beatae vitae possessionem, nos ingressuros, propter Christum, in quem credimus: cui honor \& gloria" ("Hence, the Scriptures proclaim everywhere that 'He who has Christ, with him has life and that he who believes in him, in the same way he has eternal life,' teaching that Christ is received, had, and retained by faith. And therefore through faith in Christ, we receive whatsoever leads to our Blessedness: justification, remission of sins, a peaceful conscience, sanctification, and, finally, because of Christ in whom we believe, that we shall enter into the full possession of blessed life. To him be honor and glory.").

18. $D N D$, pp. 176-88.

19. DND, p. 75: "Deinde servit haec doctrina qua docuimus naturam Dei, hoc est, essentiales Dei proprietates, nulli purae creaturae communicari posse: servit, inquam, confirmandae verae \& aeternae Deitati Christi ac Spiritus sancti: quibus in sacris literis videmus manifeste omnes Dei proprietates, simpliciter attribui: aeternitatem, immensitatem, omniscientiam, omnipotentiam, \& caeteras” (“Next, when we teach [i.e. doctrina qua docuimus] that the essential properties of God cannot be communicated to any mere creature, this serves to confirm the true and eternal deity of Christ and of the Holy Spirit, to whom we manifestly see all the properties of God simply attributed in the Holy Scriptures, namely, eternity, immensity, omniscience, omnipotence, etc.”).

20. $D N D$, p. 75: "Hinc sequitur alius: confirmatio scilicet doctrinae, de duabus distinctis in Christo naturis, distinctisque utriusque naturae proprietatibus \& actionibus, contra haersin Eutychetis: idque in una duntaxat persona, contra errorem Nestorii” (“Something else follows from this: against Eutyches' heresy the doctrine of two distinct natures in Christ together with the distinct actions and properties of either is affirmed; against the error of Nestorius, the doctrine of the single person.”).

21. $D N D$, p. 86: "Deinde ex ista simplicitate, sequitur confirmatio doctrinae de uno vero duntaxat Deo: licet tres sint personae. Quod enim simplicissimum est: id nullo modo compositum est: eoque nec multiplex. Unus igitur tantum Deus." ("Next, from that simplicity follows a confirmation of the doctrine that there is more than one true God, al- 
though there are three persons. For that which is most simple is in no way composite, and therefore not manifold. Therefore, there is only [one] God").

22. E.g., for eternity, p. 93; for immutability, p. 100; for blessedness, p. 194.

23. DND, p. 100: “Ad multa vero utilissima est haec, de immutabilitate Dei, doctrina. Principio, eo spectat, ut sciamus, qualemnam Deum colamus: Deum scilicet verum, quia immutabilem. Neque enim verus Deus esse potest: qui naturae sit, ulla ratione, mutationi obnoxiae."

24. $D N D$, p. 87: “Ac si talis est Deus: omne autem simile diligit suum simile, dissimile vero odit: fieri nequit, quin Deus oderit hypocritas, adulatores, homines duplici animo: \& contra amet sinceros, \& rectos corde. Quare, ut studeamus sinceritati, veraeque simplicitati: non obscure nos monet, Dei simplicitas... Proinde sermonem quoque nostrum, vult esse simplicem, est, est, non, non: \&, quod superest, a malo esse dicit. Et certe quos sibi eligit Deus, simplices efficit, ut parvulos. Nisi efficiamini, sicut parvuli, non intrabitis in regnum caelorum" ("And if God is thus - and if like loves like, certainly it hates that which is unlike - it cannot be but that God hates hypocrites, adulterers, double-minded men, and, contrarily, that he loves sincere people and righteous hearts. Wherefore, the simplicity of God clearly admonishes us to study sincerity and true simplicity... Thus, he desires for our speech to be simple as well: yes, yes; no, no. And whatever is beyond that, he says, is from the evil one. And, truly, those whom God chooses for himself, he makes them simple, like children. 'Unless you become like children, you will not enter the kingdom of heaven."”).

25. $D N D$, p. 514: “Quare non minus a nobis requiri intelligimus, ut odio habeamus inimicos Dei, quatenus tales sunt: quam ut Deum ipsum, \& omnes diligentes eum, diligamus: Ac proinde vitanda esse impiorum consortia: \& cum inimicis Dei nequaquam colendam esse amicitiam. Deinde discimus distinguendum esse inter homines ipsos, \& eorum vitia. Et homines quidem ipsos non esse odio habendos, quia creaturae sunt Dei, \& ideo bonae: vitia autem, omnino debere nobis venire magis ac magis in odium" ("Therefore, we understand that we are no less required to hate the enemies of God - in so far as they are enemies of God - than we are to love God and all those who love him. Hence we should avoid the company of the ungodly and by no means cultivate friendship with God's enemies. Next, we learn that we must distinguish between men themselves and their sins. Indeed, hatred should not be held against men themselves since they are creatures of God and therefore good; but we ought to come to a greater and greater hatred of their sins.").

26. DND, p. 100: "Seruit praeterea ad hoc, ut de salute nostra non dubitemus. Quid ita? Quoniam immutabilis est Deus, tum natura, tum voluntate atque fide. Cum itaque, \& velit, \& hanc suam voluntatem aperte revelarit, promiseritque, promissumque suum iureiurando etiam confirmarit, nimirum se effecturum, ut, qui in Christum credunt, vitam habeant aeternam: Qui dubitare amplius possumus de salute, si perspectum habemus, eum, ut natura, ita etiam voluntate immutabilem esse?” (“Additionally it serves this function: that we might not have doubts concerning our salvation. This is so because God is immutable as much according to [his] nature as to [his] will and [his] good faith. Therefore, since he both wills and openly reveals this as his will, and he promised, and also confirmed his promise by swearing that he would indeed bring it about that they who believe in Christ shall have eternal life. How can we doubt our salvation any longer if we have the promise of him who is immutable by nature and also by will?”) 
116/ Renaissance and Reformation / Renaissance et Réforme

27. DND, p. 59: "Denique iustitia Dei, nobis in hunc finem proponitur: ut ea sit nobis instar fraeni, quo a peccatis cohibeamur: persuasi, quod nisi resipiscamus, Deus etiamsi ad tempus sinat nos impune peccare: tamen non ita semper erit: sed ad extremum acerbissimas, verum iustissimas etiam, de nobis sumet poenas" ("Finally, the righteousness of God is displayed to us for this reason: that it might be to us the image of a bridle by which we are kept from clinging to sins and to assure us that, unless we repent, God, even though he allows us for a time to sin with impunity, nevertheless it will not always be thus, but in the end he will punish us most harshly but also most righteously.”).

28. $D N D$, p. 86: "Quum igitur aperte salutem eternam promittat hominibus iis, qui in Christum credunt, etiamsi legem non servaverint, etiamsi omnia admiserint peccata, quae admitti possint: cur dubites de salute, si vere \& ex animo credas in Christum? Deus pro sua sinceritate, \& simplicitate, nemini illudit: neminemque fallere, aut vult, aut potest.”

29. $D N D$, p. 699: "Primus itaque usus traditae doctrinae de praedestinatione est, ut hac doctrina confirmemur in certa fide ac persuasione, futurum omnino esse, ut superatis omnibus huius turbati maris fluctibus, undis, periculis, procellis, tandem in portum aeternae vitae a Christo perducamur: quia talis est voluntas \& aeternum Patris decretum...."

30. DND, p. 704: "Deinde affirmat nos, sicut ad felicitatem aeternam, sic ad temporarias hasce adflictiones esse electos, idque ut per omnia conformes simus imagini filii eius. quare sicut laetamur, quod simus electi ad aeternam vitam: sic laetandum esse in tribulationibus, quod iis similes fiamus Christo" ("Next, it affirms that just as we are elected unto eternal happiness, so also unto these temporary afflictions, and this is so that through all things we might be conformed to the image of his son. Wherefore, just as we rejoice that we are elected unto eternal life, so let us rejoice in tribulations, that by them we might be made like unto Christ.”).

31. DND, p. 702: "ut simus certi de nostra salute: quia elegit nos \& praedestinavit, ut simus sancti \& inculpati."

32. This concern does present itself briefly in De religione Christiana fides (Cambridge, 1585), a short confession of Zanchi's theology and the only mature presentation of his entire theological system. See De religione (in Op. Th., vol. 8, pt. 1, col. 486).

33. DND, p. 87: "Denique discimus, quales futuri simus in caelo: ubi Deus fuerit omnia in omnibus.”

34. DND, p. 87: "Nemo quidem simplicis essentia fiere potest: sed nulla erit in nobis mixtura peccati, mendacii, hypocriseos: sed simplicissmi fiemus corde, verbo, \& opere: quemadmodum \& Deus simplex atque sincerus est.”

35. DND, p. 93: "Deinde docet, quales futuri simus nos propter hunc Deum: aeterni scilicet: hoc est, licet cum principio, sine fine tamen, \& sine alteratione, mutationeve ulla prorsus" ("Next, it teaches what we shall be like because of this God: namely eternal, but with a beginning yet without an end, and we will be entirely without any alteration or change.”).

36. DND, p. 100: "Deinde discimus, quales futuri simus nos, immutabiles nimirum: non quidem natura, sed gratia. Cum enim ipse Deus noster, facturus sit nos sibi ipse Deus noster, facturus sit nos sibi quam similimos in caelo, ubi erimus sicut Angeli Dei, nulli amplius mutationi obnoxii...." ("Next we learn what we shall be: namely immutable, not indeed by nature, but by grace. For since our God himself has made us for himself, our God him- 
self will make us very like unto himself in heaven, where we will be just like the Angels of God, no longer liable to any change.”).

37. DND, p. 100: “...futurum videmus atque speramus, ut posita hac mortalis corporis vanitate, totiusque naturae inconstantia, ita confirmemur in gratia: ut firmam immutabilemque felicitatem cum ipso consequamur" ("Let us look to the future and let us hope so that, with this mortal body's vanity cast aside, along with all the inconstancy of nature, we might be confirmed in grace so that we may obtain a firm and immutable happiness.”).

38. DND, p. 108: “...alii diutius \& felicius, alii minus.”

39. DND, p. 108: “Quo quis propius accedit ad Christum, quod sit fide \& animo: eo magis particeps vitae fit.”

40. DND, p. 194-95: "Si vero idem, causa est nostrae Beatitatis, \& Beatitas ipsa: alibi igitur quaerenda non est, quam in Deo. Est enim ipse Deus, manifestatus in carne: eoque Immanuel effectus. In Christo igitur tota salus \& beatitas nostra, posita est. Quare nihil felicius, quam Christum habere, \& retinere. Quomodo? fiducia, qua illum, tibi datum esse, ex mera Patris gratia, \& dilectione, eoque vere totum esse tuum persuasum habeas.”

41. DND, p. 277: “...efficaciter ad Christum vocati sumus....”

42. DND, p. 438: "Accedit vero Redemptio per Christum....”

43. $D N D$, p. 698: "Unus est, certa firmaque de aeterna nostri salute in Christo, persuasio. Alter, ut omni nostrae dignitatis, meritorumque confidentia exuti: totam nostri salutem, uni gratiae Dei in Christo acceptam feramus: atque ita qui gloriatur, non in seipso, sed in Domino glorietur.”

44. DND, p. 698: "Nauta, Christus est. Ipse enim nos suo tum verbo tum Spiritu ducit in sempiternam vitam, \& ab omnibus tuetur periculis.”

45. DND, p. 718-19: “Ac proinde sciamus nunquam despondendum esse animum: sed fortiter contra hostes carnem, mundum, Satanam esse pugnandum: strenueque pergendum in pugna, donec tandem in aeternam recipiamur patriam....”

46. See above, n. 5 .

47. It should be noted that the different usus bear more than a passing resemblance to the interpretive scheme outlined in the medieval quadriga: the literal sense (Zanchi's doctrinal usus), the tropological sense (Zanchi's moral and pastoral usus), and the anagogical sense (Zanchi's eschatological usus). Zanchi does not deploy the analogical sense as a discreet type of usus, although he was clearly taken with the idea of biblical allegory. See Farthing's “Holy Harlotry” and “'De coniugio spirituali'.” The usus convention also exhibits overtones of the medieval tendency to explain the biblical texts in terms of their implications for faith (the doctrinal usus), love (the moral and pastoral usus) and hope (the eschatological usus). Zanchi, however, does not make this connection explicit. I am indebted to Dr. Richard Muller for this insight.

48. Dewey D. Wallace, Jr., Puritans and Predestination: Grace in English Protestant Theology, 1525-1695 (Chapel Hill: The University of North Carolina Press, 1982), p. 59. Wallace makes these comments with reference to Robert Hill's abridged translation of De natura Dei without noting its connection to Zanchi's treatise. This connection is explored below. 
118/ Renaissance and Reformation / Renaissance et Réforme

49. The most recent published study antedating Gründler's is Giovanni Galliziolo, Memorie, storiche e letterarie della vita e della opera di Girolamo Zanchi (Bergamo, 1785), which I have not seen.

50. The 1605 edition of Zanchi's Opera theologica contains some 6,000 folio columns. See John Patrick Donnelly, “A Sixteenth Century Case of Publish or Perish/Parish,” Sixteenth Century Journal, 6 (1975), p. 113.

51. See Merritt's comments on this phenomenon in “The pastoral tightrope," pp. 143-44.

52. Theodore Beza, Icones, id est verae imagines virorum doctrina simul et pietate illustrium ... (Geneva, 1580), fol. p2v.

53. Hendrik Hondius, Icones virorum nostra patrumque memoria illustrium (The Hague, 1599).

54. Melchior Adam, Decades duae continentes vitas theologorum exterorum principum (Frankfurt, 1618), pp. 148-53; Jean-Jacques Boissard, Bibliotheca chalcographica, hoc est virtute et eruditione clarorum virorum imagines, 9 pts. in 5 (Heidelberg and Frankfurt, 1669), pt. 7, fol. bb4.

55. Jacob Verheiden, The History of the Moderne Protestant Divines..., ed. and trans. Daniel Lupton (London, 1637), pp. 122-31. Samuel Clarke, The Marrow of Ecclesiastical Historie... (London, 1650), pp. 366-69; Thomas Fuller, Abel redivivus, or, The dead yet speaking (London, 1652), pp. 390-97; and Samuel Clarke, The Marrow of Ecclesiastical History..., 2nd ed. (London, 1654), pp. 804-07.

56. Zanchi was translated into English on a number of occasions during this period: Of the Spiritual Marriage between Christ and the Church, and every faithful man (Cambridge, 1592); “A Briefe Discourse,” in William Perkins, A case of conscience: how a man may know whether he is a child of God or no (London, 1592), pp. 37-83; His Confession of the Christian Religion (Cambridge, 1599); Life everlasting: or the true knowledge of one Jehovah, three Elohim, and Jesus Immanuel, ed. and trans. Robert Hill (Cambridge, 1601); "The Confession of Master Zanchius touching the Supper of the Lord," in Robert Hill, The pathway to prayer and pietie (London, 1613), pp. 42-62; Speculum Christianum: a Christian survey of conscience. Containing three tractates of... Hierome Zanchius, trans. Henry Nelson (London: 1614); and Jerome Zanchi to Queen Elizabeth in William Ames, Fresh Suit Against Human Ceremonies in God's Worship (Amsterdam, 1633), pp. 43-64. See also the description of the proliferation during this period of Zanchi's Latin writings in Oxford in C. M. Dent, Protestant Reformers in Elizabethan Oxford (Oxford: Oxford University Press, 1983), pp. 96-102. Regrettably, no sustained study of the history of Zanchi's English publications or of his influence on English theology and religious culture exists. The present excursus does not pretend to fill this lacuna as it focuses only on Zanchi's connection to the practical divinity tradition.

57. The title page notes only that the book is "collected out of the best moderne Divines and complied into one volume by Robert Hill....” On p. 655 Zanchi is identified in the margin as "that good man, whome I followed in that former discourse...."

58. Merritt, pp. 146-47.

59. Merritt, p. 152.

60. Merritt, p. 146. Merritt is citing Wallace, Puritans and Predestination, p. 59.

61. Merritt, pp. 147-48. 
62. Dent, p. 100.

63. William Perkins, A case of conscience... (London, 1592), sig. A2v.

64. Raymond A. Blacketer, "William Perkins (1558-1602)," in The Pietist Theologians, ed. Carter Lindberg (Oxford: Blackwell, 2005), p. 41.

65. De connubio was published as An excellent and learned treatise, of the spiritual marriage between Christ and the Church, and every faithfull man (Cambridge, 1592).

66. De religione Christiana fides was published as H. Zanchivs his confession of Christian Religion (Cambridge, 1599). A second, independent translation of De religione made by Ralph Winterton was published as The whole body of Christian religion (London, 1659).

67. Thomas Fuller, The church-history of Britain, 11 pts. in 1 (London, 1655), p. 219.

68. Primus, Richard Greenham, pp. 157, 179, and 183 points out some significant correlations between Zanchi and Greenham on their doctrine of the Sabbath.

69. See The Zurich Letters, $2^{\text {nd }}$ series, ed. and trans. Hasting Robinson (Cambridge: Cambridge University Press, 1845), pp. 81-82, 98-104, 110-12, and 271-72.

70. See, for example, Richard Greenham, learned and godly sermons, preached by that reuerende and zelous man M. Richard Greenham, ed. Henry Holland (London, 1595), fols. C1r, F4v-G1r; and Richard Greenham, Paramythion tvvo treatises of the comforting of an afflicted conscience, written by M. Richard Greenham... (London, 1598), pp. 17172. Also see Greenham's comments about determining the use of a doctrine in his The workes of the reuerend and faithfull seruant af Iesus Christ M. Richard Greenham, ed. Henry Holland (London, 1612), p. 11.

71. Kenneth L. Parker and Eric J. Carlson, 'Practical Divinity': The Work and Life of Revd Richard Greenham (Aldershot: Ashgate, 1998), p. 21.

72. Greenham, The workes, fols. L12r-Ll3r.

73. Hierome Zanchius, Speculum Christianum, or, A Christian survey of the Conscience, ed. and trans. Henry Nelson (London, 1614), sig. A4r.

74. Zanchius, Speculum Christianum, sig. A7v-A8r.

75. Dent, p. 100. See his discussion of the spread of Zanchi's works on pp. 96-102.

76. Sebastian Benefield, Doctrinae Christianae sex capita (Oxford, 1610), p. 21. Cited in Dent, p. 101.

77. See for example, John Preston, Life eternal, or, a treatise of the knowledge of the Divine Essence and Attributes (London, 1631); Henry Church, Miscellanea philo-theologica, or, God \& man (London, 1638); Richard Stock, A Stock of Divine Knowledge. Being a lively description of the Divine Nature. Or, The Divine Essence, Attributes, and Trinity particularly explained and profitably applied (London, 1641); Edward Leigh, A treatise of divinity (London, 1646); Thomas Larkham, The attributes of God unfolded, and applied (London, 1656); and Stephen Charnock, Several discourses upon the existence and attributes of God (London, 1682).

78. To mention only a few examples: Paul Baynes, The spirituall armour With which being furnished, a Christian may be able to stand fast in the euill day, and time of tryall; and to quench all the fiery darts of the wicked (London, 1620); John Preston, The saints daily exercise A treatise concerning the whole dutie of prayer. Delivered in fiue sermons 
120/ Renaissance and Reformation / Renaissance et Réforme

vpon I Thess. 5.17 (London, 1629); William Gouge, The whole-armour of God, or, A Christians spiritual furniture to keep him safe from all the assaults of Satan (London, 1639); Thomas Manton, Meate out of the eater, or, Hopes of unity in and by divided and distracted times (London, 1647); William Gurnall, The Christian in compleat armour (London, 1655); Thomas Watson, A body of practical divinity consisting of above one hundred seventy six sermons on the lesser catechism composed by the reverend assembly of divines at Westminster (London, 1692).

79. George Gifford, A briefe discourse of certaine points of the religion which is among the common sort of Christians... (London, 1581).

80. The degree to which Zanchi's reputation in England was mirrored on the Continent and the question of his connection to the foundations of the Dutch Nadere Reformatie or Continental Pietism are beyond the scope of this article, but are certainly issues worth pursuing.

81. Heinrich Heppe, Geschichte des Pietismus und der Mystik in der reformirten Kirche, namentlich der Niederlande (Leiden: Brill, 1879), p. 24. 